\title{
High Degree of Similarity between Chromatium vinosum and Chromatium minutissimum as Revealed by Riboprinting
}

\author{
JORDI MAS-CASTELLÀ, ${ }^{1 *}$ RICARDO GUERRERO, ${ }^{1}$ AND JOHAN F. DE JONCKHEERE ${ }^{2}$ \\ Department of Microbiology, University of Barcelona, 08028 Barcelona, Spain, ${ }^{1}$ and Protozoology Laboratory, Biosafety \\ and Biotechnology, Department of Microbiology, Institute of Hygiene and Epidemiology, 1050 Brussels, Belgium ${ }^{2}$
}

\begin{abstract}
The riboprinting technique (restriction fragment length polymorphism [RFLP] analysis of PCR-amplified ribosomal DNA) was used to study five strains representing three species of the genus Chromatium. An RFLP analysis following digestion of the amplified small-subunit ribosomal DNA with 25 restriction enzymes revealed that the patterns obtained for all strains of Chromatium vinosum were identical. Chromatium gracile was different from $C$. vinosum with seven enzymes. On the other hand, Chromatium minutissimum produced the same patterns as $C$. vinosum with all enzymes, indicating that these organisms have a high degree of similarity. An RFLP analysis of the PCR-amplified spacer sequence between the 16S and 23S ribosomal DNAs gave similar results except that there was a larger number of differences between $C$. gracile and the other organisms examined.
\end{abstract}

The arrangement of genera and species in the family Chromatiaceae (the purple sulfur bacteria) is based entirely on simple phenotypic characteristics. The criteria used to arrange these organisms in Bergey's Manual of Systematic Bacteriology (14) are the same as the criteria used in Bergey's Manual of Determinative Bacteriology, 8th ed. (13).

The genus Chromatium is separated from other genera of motile purple sulfur bacteria with intracellular sulfur globules by its motility, its rod-shaped morphology, and its lack of gas vacuoles. Differentiation of species within the genus Chromatium is based entirely on phenotypic characteristics (e.g., the size of cells and the color of cultures). The DNA base ratios of members of the genus ( 48.0 to $70.4 \mathrm{~mol} \% \mathrm{G}+\mathrm{C}$ ) indicate that genetically distantly related species are grouped together. At the species level, broad ranges of $\mathrm{G}+\mathrm{C}$ contents also show that some species (e.g., Chromatium vinosum $[\mathrm{G}+\mathrm{C}$ content range, 61 to $66 \mathrm{~mol} \%$ ]) may include heterogeneous collections of only phenotypically similar strains.

The genus Chromatium consists of two distinct groups based on cell size; the large Chromatium spp. include Chromatium okenii, Chromatium weissei, Chromatium warmingii, and Chromatium buderi, while the small Chromatium spp. include Chromatium minus, $C$. vinosum, Chromatium violascescens, Chromatium gracile, and Chromatium minutissimum (14).

In the group containing the small Chromatium spp. there are no characteristics that separate $C$. minutissimum and $C$. vinosum other than a difference in cell size. C. minutissimum is differentiated by its very small cell size (1 to $1.2 \mu \mathrm{m}$ wide by 2 $\mu \mathrm{m}$ long) and its rod-shaped cells. All other characteristics are the same as the characteristics of $C$. vinosum. Moreover, the $\mathrm{G}+\mathrm{C}$ content of $C$. minutissimum $(63.7 \mathrm{~mol} \%)$ falls within the range given for $C$. vinosum strains ( 61.3 to $66.3 \mathrm{~mol} \%$ ). On the other hand, the only phenotypic difference between $C$. gracile (rod-shaped cells that are 1 to $1.3 \mu \mathrm{m}$ wide and 2 to $6 \mu \mathrm{m}$ long) and $C$. vinosum is the requirement for 2 to $3 \%$ (wt/ $/ \mathrm{vol}) \mathrm{NaCl}$ for growth of the former. Most of the other characteristics of $C$. gracile are the same as $C$. vinosum characteristics. In addition, $C$. gracile can use some organic compounds, such as lac-

* Corresponding author. Mailing address: Department of Microbiolcgy, University of Barcelona, Av. Diagonal, 645, 08028 Barcelona, Spain. Phone: 34-3-4482373. Fax: 34-3-3341079. Electronic mail address: guerrero@porthos.bio.ub.es. tate, propionate, and butyrate (11). The $\mathrm{G}+\mathrm{C}$ content range of C. gracile, 68.9 to $70.6 \mathrm{~mol} \%$, is higher than the $\mathrm{G}+\mathrm{C}$ content range given for $C$. vinosum. The two other species in the group containing the small Chromatium spp. differ in more characteristics, and we included in this study only the three Chromatium spp. that are very similar. Phylogenetic relationships were established in the family Chromatiaceae by Fowler et al. (9), who included $C$. vinosum but not $C$. minutissimum or $C$. gracile in their study.

There have been extensive reports on the use of ribotyping for identification of bacteria. However, this technique is time consuming and labor intensive as hybridization procedures and, in most cases, radioactive detection are required. Therefore, we used riboprinting instead (3). In riboprinting the highly conserved small-subunit (SSU) ribosomal DNA (rDNA) is amplified by PCR, the PCR product is cut with restriction enzymes, and the resulting reaction products are separated in an agarose gel and stained with ethidium bromide. There is no need for hybridization or radioactivity when this technique is used. Riboprinting has been used with much success to distinguish species belonging to different protist genera $(2,4,6)$. Amplification of the more diverse intergenic (16S-23S) spacer region has been used frequently for the identification of bacteria. After amplification the spacer region is sequenced (10, 17) or hybridized with a specific probe (1). The numbers and sizes of the bands obtained after amplification of the spacer region have been shown to be diagnostic for species $(8,12)$. In this study we used these techniques to study the relationships of three Chromatium species.

\section{MATERIALS AND METHODS}

Bacterial strains and growth conditions. $C$. vinosum ATCC 17899. DSM 180 and DSM 185, C. minutissimum DSM 1376, and C. gracile DSM 203 were used in this study. All five strains were obtained from I. Esteve's laboratory at the Autonomous University of Barcelona, Barcelona, Spain.

Cultures were grown photolithoautotrophically in $125-\mathrm{ml}$ rubber-capped bottles at $23^{\circ} \mathrm{C}$ with 50 microeinsteins of continuous illumination $\cdot \mathrm{m}^{-2} \cdot \mathrm{s}^{-1}$. Liquid Pfennig minimal medium (18) was used to obtain a cell concentration of about $10^{8}$ cells $\mathrm{ml}^{-1}$. The axenic condition of the cultures was determined by microscopic observation.

Preparation of biological material. Cells from 25-ml portions of light-grown cultures of the five strains were collected by centrifugation, resuspended in $1.5 \mathrm{ml}$ of SE buffer (100 mM EDTA, $100 \mathrm{mM} \mathrm{NaCl}, 10 \mathrm{mM}$ Tris [pH 7.8]), and transferred to Eppendorf tubes. Sodium dodecyl sulfate $(0.1 \%)$ and proteinase $\mathrm{K}$ $(50 \mu \mathrm{g} / \mathrm{ml})$ were added to each tube, and each mixture was incubated at $37^{\circ} \mathrm{C}$ for $1 \mathrm{~h}$. The suspensions were treated with phenol-chloroform-isoamyl alcohol (50: 


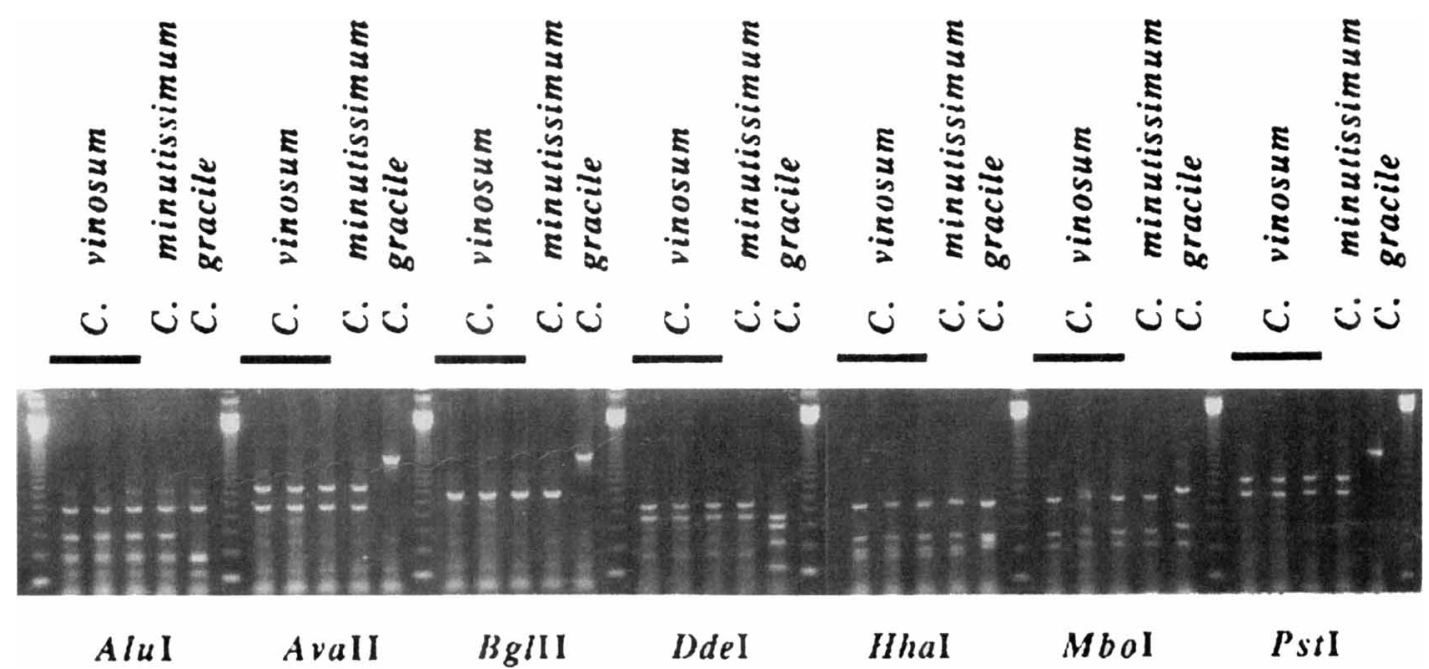

FIG. 1. RFLP analysis of the PCR-amplified SSU rDNAs (riboprinting) of the five Chromatium strains studied. C. gracile had a different riboprint than the other four strains with restriction enzymes $A l u \mathrm{I}, A v a \mathrm{II}, B g I \mathrm{II}, D d e \mathrm{I}, H h a \mathrm{I}, M b o \mathrm{I}$, and Pst $\mathrm{C}$. minutissimum and the three strains of $C$. vinosum had the same riboprint.
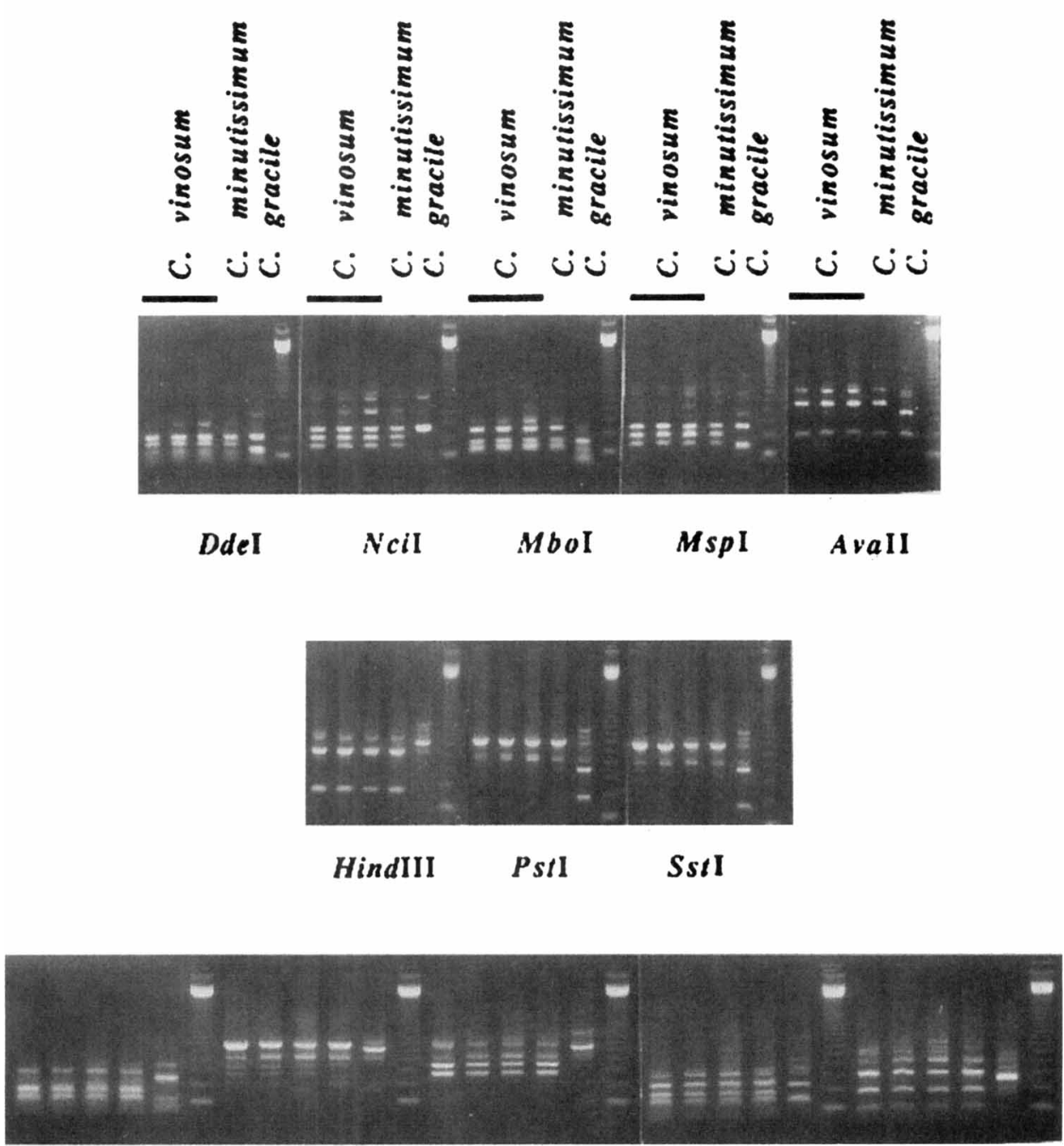
$A \mid u I$
AvaI
BanI
Hinfl
HaeIII

FIG. 2. RFLP analysis of the PCR-amplified 16S-23S ITS (riboprinting) of the five Chromatium strains studied. C. gracile had a different riboprint than the other four strains with restriction enzymes DdeI, NciI, MboI, MspI, AvaII, HindIII, PstI, SstI, AluI, AvaI, BanI, HinfI, and HaelII. C. minutissimum and the three strains of C. vinosum had the same riboprint. 
TABLE 1. RFLP analysis of the PCR-amplified SSU rRNA gene and ITS of the $16 \mathrm{~S}-23 \mathrm{~S}$ genes of $C$. vinosum, C. minutissimum, and C. gracile

\begin{tabular}{|c|c|c|}
\hline \multirow{2}{*}{ Restriction enzyme } & \multicolumn{2}{|c|}{ Results of RFLP analysis ${ }^{a}$} \\
\hline & SSU rDNA & ITS \\
\hline$A c c \mathrm{I}$ & $\mathrm{NC}$ & $\mathrm{NC}$ \\
\hline $\operatorname{Alu} \mathbf{I}$ & DIF & DIF \\
\hline Apa $\mathbf{I}$ & ID & $\mathrm{NC}$ \\
\hline AvaI & ID & DIF \\
\hline AvaII & DIF & DIF \\
\hline Bam $\mathrm{HI}$ & $\mathrm{NC}$ & $\mathrm{NC}$ \\
\hline BanI & ID & DIF \\
\hline$B g l I I$ & DIF & $\mathrm{NC}$ \\
\hline DdeI & DIF & DIF \\
\hline Eco RI & ID & $\mathrm{NC}$ \\
\hline HaeIII & ID & DIF \\
\hline HhaI & DIF & ID \\
\hline HinclI & ID & $\mathrm{NC}$ \\
\hline HindIII & $\mathrm{NC}$ & DIF \\
\hline HinfI & ID & DIF \\
\hline KpnI & $\mathrm{NC}$ & $\mathrm{NC}$ \\
\hline MboI & DIF & DIF \\
\hline MboII & $\mathrm{NC}$ & $\mathrm{NC}$ \\
\hline MspI & ID & DIF \\
\hline NciI & ID & DIF \\
\hline Pst I & DIF & DIF \\
\hline$R s a \mathrm{I}$ & ID & $\mathrm{NC}$ \\
\hline SalI & ID & $\mathrm{NC}$ \\
\hline SmaI & ID & $\mathrm{NC}$ \\
\hline Sst I & $\mathrm{NC}$ & DIF \\
\hline
\end{tabular}

${ }^{a} \mathrm{NC}$, the enzyme did not cut the DNA of any strain; ID, the patterns obtained for all strains were identical; DIF, the pattern obtained for $C$. gracile was different from the other patterns.

49:1), and the DNAs were precipitated with ethanol. RNA was eliminated by treatment with RNase $(20 \mu \mathrm{g} / \mathrm{ml})$ for $30 \mathrm{~min}$ at $37^{\circ} \mathrm{C}$. The extracted DNA was dissolved in $500 \mu \mathrm{l}$ of distilled water and stored at $-20^{\circ} \mathrm{C}$ until it was needed.

PCR amplification. PCR amplification and purification of the products were performed essentially as described previously (3) by using Taq DNA polymerase obtained from Boehringer, Mannheim, Germany. The annealing temperature was increased to $58^{\circ} \mathrm{C}$ for SSU rDNA amplification to eliminate some additional small bands obtained at $55^{\circ} \mathrm{C}$. The following primers used to amplify the gene encoding SSU rRNA were designed by comparing conserved sequences at the $5^{\prime}$ and $3^{\prime}$ ends of previously described SSU rDNAs of purple bacteria, including $C$. vinosum (GenBank accession number M26629): forward primer 5'AGAGTTTG ATCCTGGCTCAG3' and reverse primer 5'TGGTGTGACGGGCGGTGT GT3' $^{\prime}$. Two other primers were used to amplify the spacer region between the $16 \mathrm{~S}$ and 23S rRNA genes; forward primer 5'ACACACCGCCCGTCACACCA3' was complementary to the $3^{\prime}$ end of the SSU primer, and reverse primer 5'GCCAA GGCATCCACC3' was designed by comparing the $5^{\prime}$ ends of previously described bacterial large-subunit rDNA sequences. The primers were constructed by Pharmacia, Uppsala, Sweden.

In the initial analysis the PCR products were electrophoresed in $0.7 \%$ (wt/vol) agarose minigels. The oil overlay in the PCR tube was climinated by extraction with chloroform. The DNA was precipitated with ethanol and dissolved in $100 \mu \mathrm{l}$ of distilled water.

Restriction fragment length polymorphism (RFLP) analysis. The amplified SSU rDNA and spacer region DNA were treated for $1 \mathrm{~h}$ at $37^{\circ} \mathrm{C}$ with 25 restriction enzymes by using the specifications of the supplier (Life Technologies, Inc., Gaithersburg, Md.). The restriction enzymes tested were AccI, AluI, ApaI, AvaI, AvaII, BamHI, BanI, BglII, DdeI, EcoRI, HaeIII, Hha I, HincII, HindIII, HinfI, KpnI, MboI, MboII, MspI, NciI, PstI, RsaI, SalI, SmaI, and SstI.

The digested DNA was separated in $2 \%(\mathrm{wt} / \mathrm{vol})$ agarose gels together with a 123-bp DNA ladder marker (Life Technologies, Inc.) and stained with ethidium bromide.

\section{RESULTS}

SSU rDNA. The sizes of the amplified SSU rDNA products of all of the Chromatium strains investigated were the same.

Six restriction enzymes, $A c c \mathrm{I}, B a m \mathrm{HI}, H i n \mathrm{dIII}, K p n \mathrm{I}, M b o \mathrm{II}$, and $S s t$ I, did not cut any of the DNA preparations.
Nineteen restriction enzymes, AluI, ApaI, AvaI, AvaII, BanI, $B g l \mathrm{II}, D d e \mathrm{I}, E c o$ RI, HaeIII, HhaI, HincII, HinfI, MboI, MspI, NciI, PstI, SalI, SmaI, and RsaI, generated identical patterns for $C$. minutissimum and the three strains of $C$. vinosum studied. The lengths of the fragments were the lengths expected from the previously reported sequence of $C$. vinosum (GenBank accession number M26629).

A total of 7 of the 25 restriction enzymes, $A l u \mathrm{I}, A v a \mathrm{II}, B g l \mathrm{II}$, $D d e \mathrm{I}, H h a \mathrm{I}, M b o \mathrm{I}$, and Pst I, revealed differences between $C$. gracile and the four other strains studied (Fig. 1).

Spacer region. The amplified spacer region was approximately $600 \mathrm{bp}$ long in $C$. gracile and almost $700 \mathrm{bp}$ long in the other Chromatium strains. In $C$. gracile, three additional fainter bands larger than the main band were observed. In the four other strains, a fainter band smaller than the main band was observed.

Eleven restriction enzymes, AccI, ApaI, BamHI, BglII, EcoRI, HincII, KpnI, MboII, RsaI, SalI, and SmaI, did not cut any of the DNA preparations.

Fourteen restriction enzymes, AluI, AvaI, AvaII, BanI, DdeI, HaeIII, Hha I, HindIII, HinfI, MboI, MspI, NciI, PstI, and SstI, generated identical patterns for $C$. minutissimum and the three strains of $C$. vinosum.

A total of 13 of the 25 restriction enzymes, AluI, AvaI, AvaII, Ban I, DdeI, HaeIII, HindIII, HinfI, MboI, MstI, NciI, PstI, and $S s t \mathrm{I}$, revealed differences between $C$. gracile and the four other strains (Fig. 2). The data obtained in this study are summarized in Table 1.

\section{DISCUSSION}

On the basis of the identical riboprints we concluded that $C$. minutissimum is very similar to $C$. vinosum. Since only one strain of $C$. minutissimum was used and only one method was used, no conclusion concerning the relationship of these organisms can be drawn from the results of our analyses. Riboprinting is a powerful technique for clarifying the real identities of microorganisms whose morphological differences are minimal. This technique revealed that the pathogenic and nonpathogenic forms of the intestinal parasite genus Entamoeba are in fact two different species (5). A free-living amoeba that on morphological grounds was described as a Willaertia sp. turned out to be a Naegleria sp. with an aberrant life cycle when riboprinting was used (7).

In some bacterial groups in which strain isolation and cultivation are not easy, phenotypic information may not be sufficient for classification. This is the case with phototrophic bacteria. Genotypic information may help in these cases to provide greater insight into the taxonomy of the groups. Although different physiological and ecological aspects of the purple phototrophic bacteria have been described, little is known about the genetics of these organisms. Our knowledge of anoxyphotobacteria is confined to the family Rhodospirillaceae $(15,16)$. Riboprinting may be used as a fast and costeffective molecular technique to help clarify the taxonomy of special bacterial groups.

As expected, the SSU rRNA gene of Chromatium spp. is more conserved than the intergenic spacer region (internally transcribed spacer [ITS]) between the $16 \mathrm{~S}$ and $23 \mathrm{~S}$ ribosomal genes. In this study 7 and 13 of 25 restriction enzymes revealed RFLP differences between $C$. vinosum and $C$. gracile in the SSU and ITS regions, respectively. Identical RFLP patterns for the SSU and ITS regions were obtained for the three $C$. vinosum strains and the $C$. minutissimum strain. The amplified ITS of these strains were also the same size. We concluded that $C$. minutissimum is very similar to $C$. vinosum. 


\section{ACKNOWLEDGMENTS}

We thank Vicky Pavón, Núria Gaju, and Isabel Esteve of the Institute of Fundamental Biology at the Autonomous University of Barcelona for providing the Chromatium cultures.

\section{REFERENCES}

1. Barry, T., G. Colleran, M. Glennon, L. K. Dunican, and F. Gannon. 1991 The $16 \mathrm{~S} / 23 \mathrm{~S}$ ribosomal spacer region as a target for DNA probes to identify eubacteria, p. 51-56. In PCR methods and applications. Cold Spring Harbor Laboratory Press, Cold Spring Harbor, N.Y.

2. Brown, S., and J. F. De Jonckheere. 1994. Identification and phylogenetic relationships of Vahlkampfia spp. (free-living amoebae) by riboprinting. FEMS Microbiol. Lett. 115:241-246.

3. Clark, C. G. 1992. Riboprinting: a molecular approach to the identification and taxonomy of protozoa, p. D4.1-D4.4. In J. J. Lee and A. T. Soldo (ed.), Protocols in protozoology. Allen Press, Inc., Lawrence, Kans.

4. Clark, C. G., and L. S. Diamond. 1991. The Laredo strain and other Entamoeba histolytica-like amoeba are Entamoeba moshkovskii. Mol. Biochem. Parasitol. 46:11-18.

5. Clark, C. G., and L. S. Diamond. 1991. Ribosomal RNA genes of pathogenic and nonpathogenic Entamoeba histolytica are distinct. Mol. Biochem. Parasitol. 49:297-303.

6. De Jonckheere, J. F. 1994. Riboprinting of Naegleria spp.: small subunit versus large subunit. Parasitol. Res. 80:230-234.

7. De Jonckheere, J. F., and S. Brown. 1995. Willaertia minor is a species of Naegleria. Evidence that Naegleria flagellates can divide. Eur. J. Protistol. 31:58-62.

8. Dolzani, L., E. Tonin, C. Lagatolla, and C. Monti-Bragadin. 1994. Typing of Staphylococcus aureus by amplification of the 16S-23S rRNA intergenic spacer sequences. FEMS Microbiol. Lett. 119:167-174.
9. Fowler, V. J., N. Pfennig, W. Schubert, and E. Stackebrandt. 1984. Towards a phylogeny of phototrophic purple bacteria-16S rRNA oligonucleotide cataloguing of 11 species of Chromatiaceae. Arch. Microbiol. 139:382-397.

10. Gill, S., J. Belles-Isles, G. Brown, S. Gagné, C. Lemieux, J.-P. Mercier, and P. Dion. 1994. Identification of variability of ribosomal DNA spacer from Pseudomonas soil isolates. Can. J. Microbiol. 40:541-547.

11. Imhoff, J., and H. G. Trüper. 1980 . Chromatium purpuratum, sp. nov., a new species of the Chromatiaceae. Zentralbl. Bakteriol. Parasitenkd. Infektionskr. Hyg. Abt. 1 Orig. Reihe C 1:61-69.

12. Jensen, M. A., J. A. Webster, and N. Straus. 1993. Rapid identification of bacteria on the basis of polymerase chain reaction-amplified ribosomal DNA spacer polymorphisms. Appl. Environ. Microbiol. 59:945-952.

13. Pfennig, N., and H. G. Trüper. 1974. Family II. Chromatiaceae, p. 34-51. In R. E. Buchanan and N. E. Gibbons (ed.), Bergey's manual of determinative bacteriology, 8 th ed. The Williams \& Wilkins Co., Baltimore.

14. Pfennig, N., and H. G. Trüper. 1989. Anoxygenic phototrophic bacteria, p. 1635-1709. In J. T. Staley, M. P. Bryant, N. Pfennig, and J. G. Holt (ed.), Bergey's manual of systematic bacteriology, vol. 3. The Williams \& Wilkins Co., Baltimore.

15. Saunders, V. A. 1992. Genetics of the photosynthetic prokaryotes, p. 121145. In N. H. Mann and N. G. Carr (ed.), Photosynthetic prokayotes. Plenum Press, New York.

16. Scolnik, P. A., and B. L. Mars. 1987. Genetic research with photosynthetic bacteria. Annu. Rev. Microbiol. 41:703-726.

17. Uemori, T., K. Asada, I. Kato, and R. Harasawa. 1992. Amplification of the $16 \mathrm{~S}-23 \mathrm{~S}$ spacer region in rRNA operons of mycoplasmas by the polymerase chain reaction. Syst. Appl. Microbiol. 15:181-186.

18. Van Gemerden, H., and H. H. Beeftink. 1983. Ecology of phototrophic bacteria, p. 146-185. In J. G. Ormerod (ed.), The phototropic bacteria. Blackwell, Oxford. 